NEMANJA VUJČIĆ

UDC: 355.1:94(560)“-281“"

Faculty of Philosophy

University of Belgrade

nemanja.vujcic@f.bg.ac.rs

\title{
THE ARMY OF LYSIMACHUS AFTER CORUPEDIUM
}

\begin{abstract}
This paper examines the outcome of the battle of Corupedium in $281 \mathrm{BC}$, focusing on one of its important but neglected aspects: the fate of the defeated army of Lysimachus. An explanation is built around the hypothesis that it was neither annihilated on the battlefield nor disbanded after battle - the analogies with other great battles of the early Hellenistic period speak firmly against either solution. There is indirect evidence that large remnants of the defeated force remained in the service of Seleucus I and Ptolemy Ceraunus, and continued to play a role in the power struggle and wars of the years 281275 BC. Some of the more confusing events and political decisions of the time are made easier to understand and interpret if the presence of the core Macedonian troops of the former army of Lysimachus' is assumed.
\end{abstract}

The battle of Corupedium in $281 \mathrm{BC}$ was one of the pivotal moments of the early Hellenistic history. The armies of the two largest and most powerful Successor kingdoms clashed with the decisive outcome: Lysimachus lost his kingdom and his life, while Seleucus gained control over much of the Asia Minor, potentially even the large portion of the Balkans. ${ }^{1}$ For a while it seemed as if Alexander's Empire (minus Egypt) could be restored after all, under a single ruler. Alas, it wasn't meant to be. After crossing into Europe, Seleucus was murdered by Ptolemy Ceraunus (the "Thunderbolt"), who took control over the invader's army and used it to place himself on the Macedonian throne. His rule, however, proved ephemeral and the South Eastern Europe and Asia Minor were plunged into a period of wars, foreign invasions and prolonged instability.

For such an important event, the battle of Corupedium remains surprisingly obscure to us. Modern scholars, of course, tackled the

${ }^{1}$ The idea (expressed by Kosmin, P. J. The Land of the Elephant Kings: Space, Territory, and Ideology in the Seleucid Empire. Cambridge MA - London, 2014, p. 84, among others) that Seleucus intended to take possession only of Macedonia, explicitly renouncing pretension to other European dominions of Lysimachus seems rather naive, and is unsupported by the existing evidence. 
issue,$^{2}$ but meager sources deprive them of all significant details save the outcome: a crushing defeat for Lysimachus. ${ }^{3}$ We are in the dark regarding the size and composition of the opposing forces, tactics employed and casualties suffered; even the location of the battlefield was for a long time a matter of debate. ${ }^{4}$ Among several important questions

${ }^{2}$ Most important modern works on the battle, its causes and consequences: Niese, B. Geschichte der griechischen und makedonischen Staaten seit der Schlacht bei Chaeronea I. Gotha, 1893, pp. 402-407; Bevan, E. R. The House of Seleucus I. London, 1902, pp. 70-73; Bouché-Leclercq, A. Histoire des Séleucides (323-64 avant J.C.). Paris, 1913, pp. 47-51; Beloch, K. J. Griechische Geschichte IV-2². Berlin Leipzig, 1927, pp. 458-461; Tarn, W. W. The New Hellenistic Kingdoms, in: S. A. Cook, F. E. Adcock, M. P. Charlesworth (eds.), Cambridge Ancient History VII. Cambridge, 1954, pp. 96-99; Lévêque, P. Pyrrhos. Paris, 1957, pp. 259-261; Will, E. Histoire politique du monde hellénistique (323-30 av. J. C) I: De la mort d'Alexandre aux avènements d'Antiochos III et de Philippe V. Nancy 1966, pp. 84-88; Heinen, H. Untersuchungen zur hellenistischen Geschichte des 3. Jahrhunderts v. Chr: zur Geschichte der Zeit des Ptolemaios Keraunos und zum Chremonideischen Krieg. Wiesbaden, 1972, pp. 20-32; Will, E. The Formation of the Hellenistic Kingdoms, in: F. W. Walbank, A. E. Astin (eds.), Cambridge Ancient History VII-12. Cambridge, 1984, pp. 112-114; Mehl, A. Seleukos Nikator und seine Reich I: Seleukos' Leben und die Entwicklung seiner Machtposition. Louvain, 1986, pp. 295-298; Hammond, N. G. L., Walbank, F. W. A History of Macedonia III: 336-167 B.C. Oxford 1988, pp. 239246; Green, P. Alexander to Actium. The Historical Evolution of the Hellenistic Age. Berkley - Los Angeles, 1990, pp. 131-133; Lund, H. S. Lysimachus: A Study in Early Hellenistic Kingship. London - New York, 1992, pp. 199-206; Sherwin-White, S. Khurt, A. From Samarkand to Sardis: A New Approach to Seleucid Empire. Berkley Los Angeles, 1993, pp. 21-22; Делев, П. Лизимах. София, 2004, pp. 258-264; Carney, E. D. Arsinoë of Egypt and Macedon: A Royal Life. Oxford, 2013, pp. 45-48; Grainger, J. D. Seleukos Nikator: Constructing a Hellenistic Kingdom. Oxford - New York, 2014, pp. 181-183, 187-189.

${ }^{3}$ Sources for these events: Trog. Prol. 17; Memn. F 5.6 -7 (Jacoby, FGrH, 434 F 5.6-7); Paus. 1.10.3-5; 1.16.2; App. Syr. 64; Just. Ep. 17.1.9 - 17.2.2; Porphyr. 4.4 (Müller, FGH 4.4, cf. 3.4); Euseb. I 233-236 (cf. 249-250). Few details that we are told are of questionable value, except Just. Ep. 17.2.1, who says that Lysimachus died fighting. Memn. F 5.7 credits a warrior from Heraclea with striking the mortal blow. Plutarch (Moralia 970c, mentioned in 821a) and Appian (Syr. 64) give a dubious tale of king's loyal dog that protected his master's corpse and, during the king's cremation, killed himself by rushing into the pyre (the anecdote is referred to by Ael. De nat. animal. 6.25; cf. 2.40).

${ }^{4}$ That the battle took place in the vicinity of Sardis can be gauged from the preceding events. Lysimachus was caught off guard by the wintertime invasion and Seleucus westward advance was rapid. The invader managed to capture Sardis before engaging the main forces of the defense (Polyaen. 4.9.4). An epitaph for a soldier named Menas (I.Kios 98; 3rd or 2nd century BC? Cf. commentary by T. Corsten on pp. 151-153) mentions that he died in battle at a place called Kov́pov $\pi \varepsilon \delta i o v$, by the waters of the river Phrygius, i.e. in the plain west or northwest of Sardis (cf. Strab. 13.4.5; 13.4.13). Menas is praised for his achievements in battle: he killed a Thracian and a Mysian (11. 5-6); the ethnicities mentioned correspond well with what we know of the composition of Lysimachus' forces. The inscription probably refers to the battle of Corupedium, though there is still some room for doubt; in the words of Heinen, H. op. cit. p. 28: "Auch wenn die dort genannte Schlacht nicht diejenige von 281 gewesen sein sollte, so bleibt diese Inschrift dennoch für die Lokalisierung des Schlachtfeldes 
that emerge one was rarely discussed by modern scholars: the fate of Lysimachus' army after the battle. The lack of debate on this issue is to be expected, considering the scarcity of direct testimonies; scholars were reluctant to engage in what must have seemed as unfounded speculation. ${ }^{5}$ But, while it is true that no ancient author makes explicit statements about the fate of the solders of Lysimachus, important indirect testimony does exist, allowing us to form at least a solid working hypothesis.

One possibility is, of course, that there simply was no army anymore. It could have been shattered beyond recovery, ceasing to exist as a single force, or it could have been annihilated completely, there and then. Either assumption is, however, highly unlikely, especially if we keep in mind the character of the early Hellenistic warfare. The battles of this epoch are almost never fought to the annihilation of one side, usually the defeated force withdraws to regroup and fight another day, or, if it is decisively beaten (and/or lost its commander), it merely surrenders and joins the victor. After the battle of Gabiene, in $316 \mathrm{BC}$, the former army of Eumenes joined Antigonus, almost in its entirety. ${ }^{6}$ The battle of Gaza in 312 BC was decided by cavalry action and the failure of the elephant charge: the infantry of Demetrius partly fled, but eight thousands solders surrendered and were accepted by Ptolemy as military colonists. ${ }^{7}$ Even after the desperate engagement at Ipsus in $301 \mathrm{BC}$, large parts of the defeated Antigonus' army managed to disengage and flee the field, while others took up service with the victors. ${ }^{8}$ This brings us to the second possibility, that the former solders of Lysimachus (or some portion of them) were accepted into the army of Seleucus and distributed among its various formations. In this case, the army ended its life by being disassembled. I wish to explore the third possibility, which I consider to be the most likely one, given what available sources tell us, that Lysimachus' army (i.e. what was left of it after Corupedium) was preserved as a single force and continued to serve under other kings. Three kings, to be exact.

First, let us briefly look at the chronology of the main events. A cuneiform text (a fragment of the Babylonian royal chronicle) places the mobilization of Seleucus' forces and the start of a campaign in

entscheidend." It is now usually assumed that App. Syr. 62 is wrong in locating the battle in Hellespontine Phrygia. The testimony was accepted by Beloch (op. cit. pp. 459-460), but few scholars take it seriously nowadays. The same can be said for the idea that Seleucus captured Sardis after the battle, expressed by Niese, B. op. cit. pp. 404-405 (cf. p. 405, n. 1) and Bouché-Leclercq, A. op. cit. p. 48.

${ }^{5}$ Cf. Делев, П. op. cit. p. 263, n. 6.

${ }^{6}$ Diod. 19.42-43. Cf. Bosworth, A. B. The Legacy of Alexander: Politics, Warfare, and Propaganda under the Successors. Oxford, 2007, pp. 147-159.

${ }^{7}$ Diod. 19.81-84. Cf. Billows, R. A. Antigonos the One-eyed and the Creation of the Hellenistic State. Berkley - Los Angeles, 1990, pp. 124-128.

${ }^{8}$ Plut. Dem. 28-30. Cf. R. A. Billows, op. cit. pp. 181-184. 
June or July of 282 BC. ${ }^{9}$ Another cuneiform text (the Babylonian kings list, compiled in the $2^{\text {nd }}$ century BC) dates the death of Seleucus between August 25 and September 24 of 281 BC. ${ }^{10}$ Justin sets the gap between Corupedium and the king's death to seven months, thus placing the battle around February. ${ }^{11}$ In short, Seleucus entered Asia Minor at some point during the summer or autumn of $282 \mathrm{BC}$, the war was decided in the winter of $282 / 281$, Seleucus was dead by the end of the summer of 281 and Ptolemy Ceraunus was in possession of Macedonia by the winter of 281/280 at the latest. In 280 BC Pyrrhus left for Italy and early in $279 \mathrm{BC}$ Ceraunus was defeated and killed by the Celts.

Seleucus crossed into Europe in $281 \mathrm{BC}$ with an army. His intention, we are told, was to take possession of Macedonia and to spend his twilight years on the former throne of Philip and Alexander. During the crossing or soon after it, some of the troops rebelled, as is recorded in the Babylonian cuneiform chronicle. ${ }^{12}$ Following that, Seleucus was assaulted and killed by Ptolemy Ceraunus, who was part of the royal entourage. While often considered a tragic end to a great conqueror and statesman, such an occurrence was hardly unusual in the brutal and turbulent world of the Hellenistic politics: four decades earlier, Seleucus himself took part in the assassination of Perdicas. What follows, however, is a bit more puzzling and requires an explanation. Ptolemy put on the diadem and the royal robes and presented himself to the army, encamped nearby. To the surprise of several historians, the army responded without hesitation and accepted him as king. Gaining control over the troops (and, according to Memnon, a fleet), the upstart marched on Macedonia, facing little opposition. ${ }^{13}$

It seems that, although the late king had a legitimate and acknowledged successor, the army chose to put themselves in the hands of his killer, of all people. Who were these fickle solders? Certainly not the core Seleucid troops, Macedonian and Greek military settlers

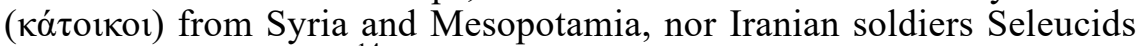
were so fond of using. ${ }^{14}$ The exceptional high level of loyalty shown by

${ }^{9}$ Glassner, J.-J. Mesopotamian Chronicles. Atlanta, 2004, no. 33, pp. 250-251; cf. Sherwin-White, S. "Babylonian Chronicle Fragments as a Source for Seleucid History". Journal of Near Eastern Studies 42, 4 (1983), pp. 266-267.

${ }^{10}$ BM 35603, obv. 6-8 (cf. Sachs, A. J., Wiseman, D. J. "A Babylonian King List of Hellenistic Period". Iraq 16, 2 (1954), pp. 202-212). There is a document from Uruk dated to co-regency of Seleucus and Antiochus, in early December of 281 BC, but this is now not considered a proof that Seleucus was alive at the time. Rather, the news of king's death did not yet reach the author of the text, or the standard formula remained unchanged for some time (ibid., pp. 205-206).

${ }^{11}$ Just. Ep. 17.2.4.

${ }^{12}$ Glassner, J.-J. op. cit. no. 33, p. 251, rev. 3-4.

${ }^{13}$ Memn. F 8.1-3; Paus. 10.19.7; Just. 17.2.4-5

${ }^{14}$ For these core troops, and the overall composition of the Seleucid forces see: Bar-Kochva, B. The Seleucid Army: Organization and Tactics in the Great Campaigns. Cambridge, 1979, pp. 20-53. 
the military settlers (unlike some other Hellenistic armies) is a wellestablished fact, recorded by the main sources and emphasized in scholarly literature. "The prevailing attitude was one of loyalty to king and dynasty... This attitude, strikingly shown by the reluctance of troops in armies of usurpers (such as Achaeus and Molon) to face the king and break oaths, was actively reinforced by royal strategies and propaganda." 15 If the incident at Lysimachia really is a case of the Seleucid troops changing allegiance right after the death of a monarch, it is the only one in the $3^{\text {rd }}$ century BC; other examples of insubordination were connected to professional issues such as the irregular wages. ${ }^{16}$ "The few sources on the composition and the obedience of the Seleucid armies reveal that the katoikoi supported Seleucid house to a very high degree. Usurpers had to face serious problems when fighting kings that were members of the Seleucid house." 17 As to other possible origins of troops, Seleucids were later known to utilize Anatolian levies, but at this stage their significant presence, except as mercenaries, is highly unlikely, Asia Minor being added to the kingdom only a few months prior. On the other hand, the soldiers led into Europe could have been mercenaries, now left without their employer and eager to take up new service. Mercenaries switching sides and changing allegiances is almost topical in the Hellenistic history, and some mercenary presence in the army is more than probable, but Seleucus would hardly utilized them as the main force to advance into Macedonia. He publicly announced his westward movement as a homecoming, a return to his native land to reclaim what was in every way his rightful possession. ${ }^{18}$ But, if his return to Europe was to be seen as such, rather than as a conquest by a foreigner, he had to use native Macedonian soldiers or, at least, their descendants. The same reasoning excludes the usage of Iranian or other Asian levies for the purpose. ${ }^{19}$

${ }^{15}$ Sherwin-White, S., Kuhrt, A. op. cit. p. 58.

${ }^{16}$ During Molon's rebellion, in the very beginning of the rule of Antiochus III, the rebel leader had to resort to direct lies (he claimed to be fighting king's corrupted advisers, not the king himself) and forged letters (that ought to convince officers that the king aims to punish them severely) to maintain the loyalty of his troops. All for nothing: upon seeing that the royal army is led by the king himself, the solders deserted to him en masse (Polyb. 5.43.4-6; 5.54.1-3; cf. 5.52.4). When Antiochus' cousin Achaeus proclaimed himself the king and attempted to lead Anatolian katoikoi into Syria, the solders refused (Polyb. 5.57.3-6) etc. The cases of disobedience from mid-2nd century $\mathrm{BC}$ onward belong to the time when the political structures of the Seleucid Empire were seriously crumbling, but even then we have numerous examples of dynastic loyalty; cf. Mittag, P. F. "Blood and Money. On the Loyalty of the Seleucid Army". Electrum 14 (2008), pp. 47-55.

${ }^{17}$ Ibid. pp. 55.

${ }^{18}$ Memn. F 8.1. Cf. Kosmin, P. J. op. cit. pp. 80-85.

${ }^{19}$ This and other reasons make the conclusion reached by Hammond N. G. L., Walbank, F. W. op. cit. p. 243 highly improbable: “The size of Seleucus' army is not recorded, but it must have been substantially the force which had gained the victory at Corupedium, perhaps reinforced by some of Lysimachus' defeated troops." Transferring 
The simplest explanation for the untypical behavior of these Seleucid troops is that they were not Seleucid at all. They were what was left of the European army of Lysimachus: Macedonians, Greeks from the seaboard of Macedonia and Thrace, probably some Thracian troops too. ${ }^{20}$ This likely scenario was assumed long ago by Niese (,Wahrscheinlich waren es die ehemaligen Truppen des Lysimachos, die Seleukos nach Europa hinüberführte."), ${ }^{21}$ but few scholars have seriously considered it since. ${ }^{22}$ In acting as Seleucus' escort to Macedonia, the soldiers were returning home. When defeated and left without their king (and dynasty as such, Agathocles being dead as well, Arsinoe and her children fleeing across the sea $)^{23}$ they did the sensible thing and accepted the victor as their new master. But their loyalty to him or his house was not and could not have been very deep and, after his death, they felt no qualms about crowning his assassin. Indeed, some of them probably felt that justice has been served.

The former army of Lysimachus was now in the hands of Ptolemy Ceraunus. But this too was a marriage of opportunity and soldiers probably weren't overly enthusiastic about this king either. They were already rebellious under Seleucus and it is likely that Ceraunus too had difficulties controlling them. How long did they remain in his service? At first and by necessity, he certainly made much use of them, as he was clearly able to fend off various threats. An attempt by Antigonus Gonatas to assert himself in Macedonia was beaten back, using the former fleet of Lysimachus (the same ships were employed by Seleucus to cross into Europe in the first place); Ceraunus and Gonatas remained hostile to each other. ${ }^{24}$ His half-sister Arsinoe, now in possession of Cassandrea, still commanded some influence and armed forces, but he convinced her to come to terms, a decision that eventually meant the death of her children. ${ }^{25}$ Another opponent was an Illyrian

anything close to the maximal Seleucid field army (such as the one that must have been employed at Curupedium), i.e. many tens of thousands of soldiers, across the sea to take possession of otherwise defenseless dominions of Lysimachus would have been a prohibitively expensive and logistically difficult venture - with hardly any solid reasoning behind it. And what forces would be available to Antiochus in Asia in the meantime? Bevan, E. R. op. cit. p. 73 made a similar claim ("Seleucus crossed the Hellespont into Europe... The main part of the army accompanied him and was quartered at Lysimachia.") without stating the reasons for it.

${ }^{20}$ Pausanias 1.16.2 claims that "there was an army of both Greeks and barbarians

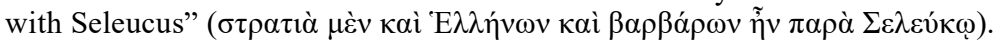

${ }^{21}$ B. Niese, op. cit. p. 407.

${ }^{22}$ Heinen, H. op. cit. pp. 62-63, n. 234 entertains the idea briefly.

23 The queen was in Ephesus (with her children, presumably) at the time of the battle at Corupedium (Polyaen. 8.57).

${ }^{24}$ Memn. F 8.4-6; Just. 24.1.1.

25 The story is given twice by Justin (Just. 17.2.4-8; 24.2-3), the two versions are not exactly in line with each other, cf. E. D. Carney, op. cit. pp. 49-51. 
king (probably of the Taulantii) named Monunius, ${ }^{26}$ who supported a pretender to the Macedonian throne, Ptolemy son of Lysimachus. Only one source mentions this, without other details including the outcome, but it is clear that Ceraunus was successful in countering the threat. ${ }^{27}$ However, there is no proof that he took control of the entirety of the former European kingdom of Lysimachus, although some historians assume this. ${ }^{28}$ Given the short span of his rule and the numerous problems he encountered this doesn't seem probable or even possible. ${ }^{29}$

Justin mentions that Ptolemy was briefly at war with Antiochus I and Pyrrhus of Epirus, who himself had a stronger claim to Macedonian throne. However, he was soon able to make peace with both of them; ${ }^{30}$ in the case of Pyrrhus the deal was cemented by a loan of troops. Upon deciding to lead an army into Italy, Pyrrhus asked (petit) for assistance from several Greco-Macedonian kings. The request met with surprising success. In the words of Justin:

Itaque Tarentinis adversus Romanos laturus auxilium ab Antigono naves ad exercitum in Italiam deportandum mutuo petit, ab Antiocho pecuniam, qui opibus quam militibus instructior erat, ab Ptolomeo Macedonum militum auxilia. Sed Ptolomeus, cui nulla dilationis ex infirmitate virium venia esset, quinque milia peditum, equitum IV milia, elephantos $L$ non amplius quam in biennii usum dedit. Ob haec Pyrrhhus filia Ptolomei in matrimonium accepta vindicem eum regni reliquit, pacificatus cum omnibus finitimis, ne abducta in Italiam iuventute praedam hostibus regnum relinqueret.

And so, upon deciding to help Tarentines against Romans, he asked Antigonus for ships to transfer troops to Italy, Antiochus for money, for he was better supplied with riches than with soldiers,

${ }^{26}$ Monunius is often referred in modern literature as the king of the Dardani (cf. Hammond, N. G. L. "The Kingdoms in Illyria circa 400-167 B.C." The Annual of the British School at Athens 61 (1966), p. 246; Wilkes, J. The Illyrians, Oxford 1996. p. 146; Mørkholm, O. Early Hellenistic Coinage: From the Accession of Alexander to the Peace of Apamea (336 - 188 B.C.). Cambridge, 2001, pp. 83-84); furthermore, he is sometimes identified with the unnamed king of the Dardani who offered military aid to Ceraunus prior to the Celtic invasion. No ancient source supports either claim and on the whole the identification is not very likely. King Monunius of the early 3rd century $\mathrm{BC}$ is well-known from his coins, minted in Epidamnus, in the land of the Taulantii (Mørkholm, O. loc. cit.). During the World War I a helmet with the inscribed name of the king (MONOYNIOY $[B A] \Sigma I \Lambda E \Omega[\Sigma]$ ) was found in the lake Ohrid. Cf. Papazoglou, F. «Un témoignage inaperçu sur Monounios l'Illyrien ». Živa antika / Antiquité Vivante 21, 1 (1971), pp. 177-184; Rendić-Miočević, D. „Ilirske onomastičke studije (IV)“. Živa antika / Antiquité Vivante 21, 2 (1971), pp. 386-387; Heinen, H. op. cit. pp. 84-87.

27 Trog. Prol. 24.

${ }^{28}$ Cf. Hammond, N. G. L., Walbank, F. W. op. cit. p. 248.

${ }^{29}$ For a detailed discussion of the chronology of Ceraunus' reign see Heinen, H. op. cit. pp. 54-61.

30 Trog. Prol. 17. 
and Ptolemy for Macedonian troops. And indeed Ptolemy, who had no excuse to delay because of the lack of forces, gave him five thousand footmen, four thousand cavalry, and fifty elephants, for no more than two years'service. Because of this Pyrrhus took Ptolemy's daughter as a wife and left him as the protector of his kingdom, making peace with all the neighbors, so that, when he takes the able-bodied men to Italy, the kingdom is not left to the enemies.

(Just. Ep. 17.2.13-15. My translation and italics)

Two points emerge immediately: Ptolemy Ceraunus had forces to spare, and he was willing to share them with Pyrrhus - a strange example of unselfishness among otherwise self-serving and competitive Hellenistic rulers! But is any of this really the case? Less than a year later, Macedonians under Ptolemy suffered what was probably the biggest military defeat in their history (certainly up to this point), at the hands of Celts. Macedonian army was crushed, the upstart king lost his life, and the country was overrun, left without defense or recognized government. Suddenly, it seems that Ceraunus lacked sufficient forces even for the defense of Macedonia proper. Thus, this peculiar loan of otherwise badly needed soldiers demands a comment.

It could be assumed that Ceraunus was acting out of fear, that Pyrrhus threatened him with war, demanding troops or else, although this is not suggested by Justin's words. Something similar did happen between Pyrrhus and Antigonus Gonatas five years later. ${ }^{31}$ But sources do not present Ptolemy Ceraunus as fearful or cautious, rather, he seems to be exceedingly self-confident and overbold. ${ }^{32}$ And, furthermore, what was there to fear if he was remarkably well supplied with troops? Pyrrhus was the one asking for military aid. Here the simplest explanation is that there were some issues with the troops: for example, that he was not able to pay them regularly, or that he had difficulties controlling them, or both. The arrangement with Pyrrhus meant that the troublesome troops would be across the sea for a while, causing concerns to someone else. And with the Epirote king far away in Italy, it might well have seemed that there were no serious military challenges, at least for the conceivable future. The native military power of Macedonia would be restored gradually and in the meanwhile even the diminished forces would be sufficient. In this he miscalculated, of course, but it might have seemed as sound reasoning at the time.

This explanation fits well with the hypothesis that the loaned troops were from the Macedonian core of the army of Lysimachus.

${ }^{31}$ Just. Ep. 25.3.1-2; cf. Plut. Pyrrh. 26.1-5.

32 Diod. 22.3.1; Justin Ep. 24.4.8-5.7. There are, however, issues with some of these authors' statements, mainly that they insist on presenting Ceraunus as an inexperienced and foolish young man rushing into his doom, whereas he was well in his thirties at the time, and had significant experience as statesman and military leader. 
They were highly efficient and battle-hardened but also of questionable loyalty and, perhaps, given the resources available to Ceraunus, difficult to maintain. Their absence can help to explain Macedonian failure to resist the marauding Celts and actually Justin says that Ptolemy met them "with few disorganized troops" (cum paucis et incompositis). ${ }^{33}$ We should avoid falling under the spell of the later Greco-Roman imagery that paints the Celtic invaders of $279 \mathrm{BC}$ as innumerable hordes of cruel and fearless savages, pouring in many tens or even hundreds of thousands from Central Europe in search of plunder and destruction. ${ }^{34}$ The fact that they were decisively beaten by comparatively small opposing forces (Greek allies at Delphi in $279 \mathrm{BC}$, Gonatas' small host in $277 \mathrm{BC}$ ) points to the opposite conclusion: these were warrior bands of moderate size that would hardly pose a threat to Macedonian kingdom in its prime. However, by this time, Macedonia was seriously deprived of population due to the stress imposed by the conquests of Alexander and the incessant warfare of the diadochi. The exact degree of this decay was the subject of a prolonged academic debate that was unfortunately (though perhaps unavoidably) muddled by the scholars' perception of Alexander the Great. ${ }^{35}$ Taking everything

${ }^{33}$ Just. Ep. 24.4.8: "Solus rex Macedoniae Ptolomeus adventum Gallorum intrepidus audivit eisque cum paucis et incompositis, quasi bella non difficilius quam scelera patrarentur, parricidiorum furiis agitatus occurrit."

${ }^{34}$ Paus. 10.19.7-12 and Just. 24.4.1-7 provide some very strong examples of this imagery. According to them, the Gauls pushing south were numbering hundreds of thousands, they were "violent, bold and warlike folk" ("gens aspera, audax, bellicosa"), brutalities they committed in Paeonia, Thrace, Macedonia and Thessaly spread terror amongst the Greeks but also stiffened the resolve of the defenders etc.

${ }^{35}$ The older historiography mostly took for granted that Macedonia suffered because of this drainage of manpower. Even W. W. Tarn, a historian most associated with the trend of excessive idealization and glorification of Alexander the Great, considered the decline of the country an obvious fact, cf. Tarn, W. W. Antigonos Gonatas. Oxford 1913, p. 64 (assessing the situation during the rule of Demetrius Poliorcetes): "Macedonia was thinly populated, and had never been able to raise field armies in proportion to its size; still less cold it do so now, with provinces shorn away, exhausted by many wars, and terribly in need of time to recuperate." That Alexander's conquest had negative, indeed debilitating, effect on Macedonia was argued by Bosworth, A. B. "Alexander the Great and the Decline of Macedon”, Journal of Hellenic Studies 106 (1986), pp. 112 (cf. Walbank, F. W. Macedonia and Greece, in: F. W. Walbank, A. E. Astin (eds.), Cambridge Ancient History VII-12. Cambridge, 1984, p. 225). Bosworth's article prompted a long and somewhat heated debate. Major exponents of the opposing view were Hammond, N. G. L. "Casualties and Reinforcements of Citizen Soldiers in Greece and Macedonia", Journal of Hellenic Studies 109 (1989), pp. 66-68; Badian, E. Agis III: revisions and reflections, in: I. Worthington (ed.), Ventures into Greek History. Oxford, 1994, pp. 261-268; and Billows, R. A. Kings \& Colonists: Aspects of Macedonian Imperialism. Leiden - New York - Köln, 1995, pp. 183-212. Some of the Bosworth's critics accepted a serious fall in the country's population by the $270 \mathrm{~s}$ BC, but shifted the blame to the Celtic invasion and its consequences. While conceding some points to the critics, Bosworth stuck to his main conclusion, cf. Bosworth, A. B. The Legacy of Alexander: Politics, Warfare, and Propaganda under the Successors. Oxford, 2002, pp. 64-97, the chapter "Macedonian Numbers at the Death of Alexander". 
into consideration, I think there can be little doubt that the population of Macedonia in 280s BC was seriously affected by the previous half a century of warfare and emigration. ${ }^{36}$ If we add the loss of territories and the presumed deterioration in economic activity, it becomes clear that Ceraunus took over a seriously impoverished kingdom. Thus, the temporary success of the Celtic incursion was not the cause but a symptom of the country's decline.

Elephants are a significant part of the equation because they point out the origin of the loaned forces. Any elephants that Ptolemy had must have come from the armies of either Lysimachus or Seleucus, most likely the latter. War elephants were important for the Seleucids, ${ }^{37}$ both symbolically, as a source of prestige, and as a battlefield weapon - it stands to reason that Seleucus would take some to Europe. Though no source mentions it, it is not impossible that Lysimachus too had some elephants in his army during the Corupedium campaign, though these would be imported animals or the last remnants of the Antigonus' herd (75 animals in total at Ipsus, compared to Seleucus' 400). ${ }^{38}$ Either assumption leads to the conclusion that they were a part of the army that Ptolemy took over in Lysimachia in $281 \mathrm{BC}$. And Ceraunus didn't lend all of them to Pyrrhus - he had some even in the final engagement with the Celts. ${ }^{39}$

There is, of course, plenty of room for questioning the figures given by Justin. He is not known to be the most reliable author, and the proportion of cavalry to infantry seems unrealistically high (4:5). Furthermore, Plutarch claims that Pyrrhus brought with him only three thousand horsemen and mere twenty elephants (besides 20,000 footmen, two thousand archers and five hundred slingers). ${ }^{40}$ Whatever

${ }^{36}$ The demographic decline is well attested, there are both direct and indirect testimonies. When speaking of the difficulties that Antipater had in organizing response to the Greek uprising of 323 BC, Diodorus says (18.12.2): "Macedonia was lacking in ci-

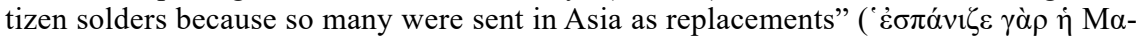

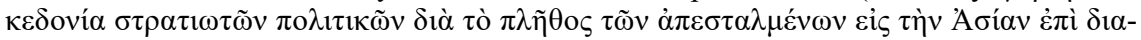
$\delta o \chi \eta े v)$. The literary sources clearly show that Macedonian military potential after Alexander's death was far bellow of that in his and his father's time. The only evidence to the contrary is Plutarch's claim (Demet. 43.2-3; Pyrrh. 10.3) about an enormous army allegedly created by Demetrius Poliorcetes in the early 280s BC. The claim cannot survive serious scrutiny, see my paper published in: Maksimović, Lj., Ricl M. (eds.) TH ПРО -

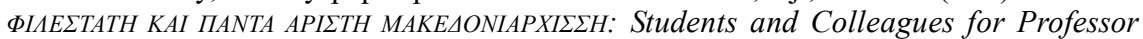
Fanoula Papazoglou (International Conference, Belgrade, October 17-18, 2017). Belgrade, 2018, pp. 221-241.

${ }^{37}$ Bar-Kochva, B. op. cit. pp. 75-83; Sherwin-White, S., Khurt, A. op. cit. pp. 1213, 53; Kosmin, P. J. op. cit. p. 3; cf. Launey, M. Recherches sur les armées hellénistiques I. Paris, 1949, pp. 586-589.

${ }^{38}$ Plut. Demet. 28.3.

${ }^{39}$ According to Memn. F 8.8 Ptolemy rode on one in battle, and was captured by

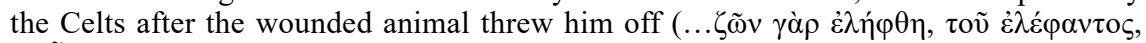

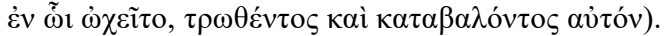

${ }^{40}$ Plut. Pyrrh. 15.1. Cf. P. Lévêque, op. cit. pp. 295-296. 
happened to the rest? The easiest way to evade the issue is to presume an error on Justin's part, and this is sometimes done, with numbers emended to 5,000 foot, 400-1000 cavalry, and even as little as five elephants. ${ }^{41}$ It should be noted that transporting cavalry, let alone elephants, across the sea was a major feat in Antiquity, and that Pyrrhus was probably the first to carry over so many elephants over such large body of water. ${ }^{42}$ Mistakes and casualties are to be expected and this is in fact confirmed by Plutarch. ${ }^{43}$ On the other hand, Plutarch could be wrong as well, as he often is, especially with this kind of information. In that case there is little we can do to fix the numbers. Some historians suggested that Pyrrhus simply didn't take all of the Macedonian forces lent to him at once (the great crossing mentioned by Plutarch), but initially left some of them in Epirus, to be transferred at a later date. ${ }^{44}$

Additionally, if we assume that the troops loaned were the Macedonian core of the army of Lysimachus, their numbers are not as unrealistic. Perhaps Ceraunus had more cavalry to spare, because they survived the engagement in greater numbers. There are several examples of major Hellenistic battles during which cavalry took much smaller losses than infantry. As far as the non-Macedonian troops in $\mathrm{Ce}-$ raunus' service are concerned, we are in the total darkness. They could have been disbanded by this point, due to the scarcity of resources. Anatolian part of the Lysimachus' forces were probably not taken to Europe at all by Seleucus: they would have been either disbanded immediately after the battle or employed closer to their homelands, and it is questionable whether Lysimachus even managed to utilize the full military potential of his Asian domains, given the sedition of the various cities and generals and the surprising and swift advance of the enemy. ${ }^{45}$ If he was forced to fight the final battle mainly with his European levies, that would have been a significant factor in Seleucus' victory.

To sum up, one possible hypothesis is that the former troops of Lysimachus, or at least their significant remains, were in service of Seleucus I and Ptolemy Ceraunus in turn, to be finally taken to Italy by Pyrrhus to fight the Romans. With the addition of these numerous and experienced troops the Epirote king was in a position to assemble his largest army to date, indeed large and efficient enough to defeat Roman legionaries in several engagements. What became of them in the end? Already in 279 BC Ceraunus was dead, making any arrangement

${ }^{41}$ Cf. ibid., p. 278, n. 2. For a more extensive discussion of the number of elephants in Pyrrhus' army see Heinen, H. op. cit. pp. 72-74 and Garoufalias, P. Pyrrhus: King of Epirus. London, 1979, pp. 321-322.

42 Ibid. pp. 264-266, 297-298.

${ }^{43}$ Plut. Pyrrh. 15.1-5.

${ }^{44}$ So Hammond, N. G. L., Walbank, F. W. op. cit. p. 246, n. 4.

${ }^{45}$ If I.Kios 98 actually refers to the battle of Corupedium, it proves that Mysians were included in the army of Lysimachus, see n. 4. 
between him and Pyrrhus defunct. The solders most likely remained in the service of the Epirote king, as a kind of elite mercenaries. They would certainly be utilized in all the major battles with the Romans and the Carthaginians and their numbers would steadily diminish through the years of intensive fighting. When he finally left Italy, Pyrrhus had with him a mere eight thousand foot and five hundred cavalry, less than one third of the initial army. ${ }^{46}$ It is possible that at least some of the Lysimachus' soldiers lived long enough to return to their homeland when Pyrrhus briefly took Macedonia from Antigonus. Or even to follow him into further ventures and to his death on the streets of Argos. But we'll never know for sure.

\title{
BIBLIOGRAPHY
}

\author{
Ancient Authors:
}

Appian's Roman History II, trans. H. White. London - Cambridge MA, 1972.

Claudius Aelianus. De Natura Animalium, ed. M. G. Valdés, L. A. L. Fueyo, L. R.-N. Guillén. Berlin, 2009.

Diodorus of Sicily. IX: Books XVIII and XIX 1-65, trans. R. M. Geer. Cambridge MA London, 1962.

Diodorus of Sicily. X: Books XIX 66-100 and XX, trans. R. M. Geer. Cambridge MA London, 1962.

Diodorus of Sicily. XI: Fragments of Books XXI-XXXII, trans. F. R. Walton. Cambridge MA - London, 1962.

Eusebi Chronicorum liber prior, ed. A. Schoene. Berlin, 1875.

The Geography of Strabo VI: Books XIII-XIV, trans. H. L. Jones. London - Cambridge MA, 1970.

Glassner, J.-J. Mesopotamian Chronicles. Atlanta, 2004.

Jacoby, F. Die Fragmente der griechischen Historiker III B. Leiden, 1950.

Justin. Epitoma Historiarum Philippicarum Pompeii Trogi, trad. M.-P. Arnaud-Lindet. 2003 (http://www.forumromanum.org/literature/justin/index.html, accessed on 10/11/19)

Müller, C. Fragmenta historicorum graecorum. Paris, 1883.

Pausanias. Description of Greece I, trans. W. H. S. Jones. London - Cambridge MA, 1959.

Pausanias. Description of Greece IV, trans. W. H. S. Jones. Cambridge MA - London 1965.

Plutarch's Lives IX, trans. B. Perrin. Cambridge MA - London, 1958.

Plutarch's Moralia X, trans. H. N. Fowler. Cambridge MA - London, 1969.

Plutarch's Moralia XII, trans. H. Cherniss, W. Helmbold. Cambridge MA - London, 1968.

Polyaeni Strategematon libri octo, rec. E. Woelfflin. Leipzig, 1887.

Polybius. The Histories III, trans. W. R. Patton. Cambridge MA - London, 1979.

Sachs, A. J., Wiseman, D. J. "A Babylonian King List of Hellenistic Period". Iraq 16, 2 (1954), pp. 202-212.

${ }^{46}$ Plut. Pyrrh. 26.2; cf. Diod. 22.6.2. 


\section{Epigraphic Corpora:}

Thomas, C. Die Inschriften von Kios. Inschriften griechischer Städte aus Kleinasien 29. Bonn, 1985.

\section{Literature:}

Badian, E. Agis III: revisions and reflections, in: I. Worthington (ed.), Ventures into Greek History. Oxford, 1994, pp. 258-292.

Bar-Kochva, B. The Seleucid Army: Organization and Tactics in the Great Campaigns. Cambridge, 1979.

Beloch, K. J. Griechische Geschichte IV-2². Berlin - Leipzig, 1927.

Bevan, E. R. The House of Seleucus I. London, 1902.

Billows, R. A. Antigonos the One-eyed and the Creation of the Hellenistic State, Berkley - Los Angeles, 1990.

Billows, R. A. Kings \& Colonists: Aspects of Macedonian Imperialism. Leiden - New York - Köln, 1995.

Bosworth, A. B. "Alexander the Great and the Decline of Macedon". Journal of Hellenic Studies 106 (1986), pp. 1-12.

Bosworth, A. B. The Legacy of Alexander: Politics, Warfare, and Propaganda under the Successors, Oxford, 2007.

Carney E. D. Arsinoë of Egypt and Macedon: A Royal Life. Oxford, 2013.

Garoufalias, P. Pyrrhus: King of Epirus. London, 1979.

Grainger, J. D. Seleukos Nikator: Constructing a Hellenistic Kingdom. Oxford - New York, 2014.

Green, P. Alexander to Actium. The Historical Evolution of the Hellenistic Age. Berkley Los Angeles, 1990.

Heinen, H. Untersuchungen zur hellenistischen Geschichte des 3. Jahrhunderts v. Chr: zur Geschichte der Zeit des Ptolemaios Keraunos und zum Chremonideischen Krieg. Wiesbaden, 1972.

Hammond, N. G. L. "The Kingdoms in Illyria circa 400-167 B.C". The Annual of the British School at Athens 61 (1966), pp. 239-253.

Hammond, N. G. L. "Casualties and Reinforcements of Citizen Soldiers in Greece and Macedonia”. Journal of Hellenic Studies 109 (1989), pp. 56-68.

Hammond, N. G. L., Walbank, F. W. A History of Macedonia III: 336-167 B.C. Oxford 1988.

Kosmin, P. J. The Land of the Elephant Kings: Space, Territory, and Ideology in the Seleucid Empire. Cambridge MA - London, 2014.

Launey, M. Recherches sur les armées hellénistiques I-II. Paris, 1949-50.

Lévêque, P. Pyrrhos. Paris, 1957.

Lund, H. S. Lysimachus: A Study in Early Hellenistic Kingship. London - New York, 1992.

Mehl, A. Seleukos Nikator und seine Reich I: Seleukos' Leben und die Entwicklung seiner Machtposition. Louvain, 1986.

Mittag, P. F. Blood and Money. On the Loyalty of the Seleucid Army. Electrum 14 (2008), pp. 47-55.

Mørkholm, O. Early Hellenistic Coinage: From the Accession of Alexander to the Peace of Apamea (336 - 188 B.C.). Cambridge, 2001.

Niese, B. Geschichte der griechischen und makedonischen Staaten seit der Schlacht bei Chaeronea I. Gotha, 1893.

Papazoglou, F. «Un témoignage inaperçu sur Monounios l'Illyrien ». Živa antika / Antiquité Vivante 21, 1 (1971), pp. 177-184. 
Rendić-Miočević, D. „Ilirske onomastičke studije (IV)“. Živa antika / Antiquité Vivante 21, 2 (1971), pp. 381-397.

Sherwin-White, S. "Babylonian Chronicle Fragments as a Source for Seleucid History". Journal of Near Eastern Studies, 42, 4 (1983), pp. 265-270.

Sherwin-White, S., Khurt, A. From Samarkand to Sardis: A New Approach to Seleucid Empire. Berkley - Los Angeles, 1993.

Tarn, W. W. Antigonos Gonatas. Oxford, 1913.

Tarn, W. W. The New Hellenistic Kingdoms, in: S. A. Cook, F. E. Adcock, M. P. Charlesworth (eds.), CAH VII. Cambridge, 1954.

Vujčić, N. The Grand Army of Demetrius Poliorcetes, in: Lj. Maksimović, M. Ricl (eds.),

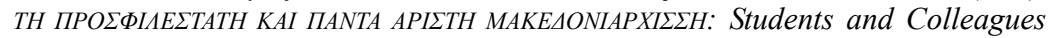
for Professor Fanoula Papazoglou (International Conference, Belgrade, October 17-18, 2017). Belgrade, 2018, pp. 221-241.

Walbank, F. W. Macedonia and Greece, in: F. W. Walbank, A. E. Astin (eds.), CAH VII12. Cambridge, 1984

Will, E. The Formation of the Hellenistic Kingdoms, in: F. W. Walbank, A. E. Astin (eds.), CAH VII-12. Cambridge, 1984.

Wilkes, J. The Illyrians. Oxford 1996.

Делев, П., Лизимах. София, 2004. 